\title{
Comparative Effectiveness of Cyanoacrylate Bioadhesives and Monofilament Suture in Wound Healing: A Histopathological and Physicochemical Study in New Zealand White Rabbit
}

\author{
Angulo $\mathrm{A}^{1 *}$, Sebastián $\mathrm{I}^{2}$, Martínez $\mathrm{FJ}^{2}$, Torregrosa $\mathrm{R}^{3}$, Martín-Martínez $\mathrm{JM}^{3}$ and Madariaga $\mathrm{AM}^{2}$ \\ ${ }^{1}$ Optics, Pharmacology and Anatomy Department, University of Alicante, 03080 Alicante, Spain \\ ${ }^{2}$ Animal House Facilities, Research Technical Services, University of Alicante, 03080 Alicante, Spain \\ ${ }^{3}$ Adhesion and Adhesives Laboratory, University of Alicante, 03080 Alicante, Spain
}

\begin{abstract}
Comparative performance of suture and cyanoacrylate adhesives of different alkyl chain length for wound healing were compared in-vivo in New Zealand White rabbits. The alkyl chain length of the cyanoacrylate adhesive determines its effectiveness in tissue repair. The n-butyl cyanoacrylate (BCN) adhesive is very aggressive on the rabbit skin due to high exothermal reaction whereas wound closures with ethyl cyanoacrylate (ECN) and n-octyl cyanoacrylate $(\mathrm{OCN})$ are adequate and similar. No significant alterations were found in the standard biochemical and haematological parameters test. When ECN and OCN adhesives are used, the wounds close with little inflammation, the edges are not separated and the tissues throughout the joined areas and nearby are normal. However, due to BCN stiffness, closed wounds show opened edges and intense inflammation. ECN and $\mathrm{OCN}$ adhesives present advantages vs. suture, i.e. less time for application, good confrontation of both sides of the incision, immediate haemostasis, less inflammation and absence of infection.
\end{abstract}

Keywords: Bioadhesives; Inflammation; Monofilament suture; Rabbit; Wound healing

\section{Introduction}

The rabbit is an important animal model in biomedical research and has a valuable economic role in animal production as much of the information on rabbit health and care were related primarily to those animals bred for meat, or kept in research laboratories. In the last decades rabbits became companion animals and their owners demand the highest standards of care for their rabbits, a demand of more and better information on the veterinary treatment of this species has been created [1].

Furthermore, the growing interest and respect for animal welfare, the application of the rule of the 3Rs, of Replacement, Reduce and Refinements the animals used in research [2], the refinement of techniques to prevent animal suffering, impart greater value in having methods of non-invasive wound closure which should be instantaneous, shortening the downtime and/or anaesthesia of the animal, producing better recovery and being less traumatic, especially considering that rabbit skin is very sensitive as its tear easily when stretched or cut its hair with razor or shaving. Since Elizabethan collars are not well tolerated by these animals, the use of subcuticular sutures for skin closure are recommended, or alternatively, the application of tissue adhesive or skin staples [3].

One of the advantages of using tissue adhesives for joining animal or human tissues as compared to the traditional suture is the creation of homogeneous and uniform distribution of stresses all along the joint. Furthermore, the tissue adhesives are easy to apply, they are less traumatic to patient, their use reduces the surgical time, avoids the mechanical damage produced in the tissues by suture, inhibit scar formation, and there is no need of sutures or bandages removal after surgical practice. Several tissue cyanoacrylate adhesives have been developed. These adhesives polymerize in the presence of water and because skin has a high concentration of water, these adhesives can be used for surgical practice and wound closure. Cyanoacrylate adhesives also produce strong and quick adhesion in wound closure.

Since 1950 cyanoacrylate adhesives have been used [4]. Several studies [5-11] have shown their effectiveness as an alternative to suture practice. Particularly, cyanoacrylate adhesives have shown excellent performance as skin adhesives, surgical glues and embolic materials $[5,6]$, in skin closure in plastic surgery or in osteosynthesis (ethyl cyanoacrylate polymerized by ultrasounds) $[7,8]$, in the therapeutic embolization of cerebral arteriovenous malformations, in gastric variceal bleeding or corneal perforations [9], in ocular strabismus surgery [10], in eyelid wound closure in rabbits [11] and as skin sealants for plastic surgery. In all these applications, similar performance in wound closure was obtained by using the suture and the adhesives.

Although medical use of cyanoacrylate adhesives goes back to the half of the last century, especially for army applications, only in the last two decades the US Food and Drug Administration (FDA) approved the use of cyanoacrylates in humans [12]. However, despite producing effective sealing, the use of cyanoacrylate adhesives showed exothermal cureandhigh stiff polymerized product of considerable strength but fragile at the same time. In addition, erosion, ulceration, and areas of necrosis in surrounding (or adjacent) tissues may occur. One easy route to reduce the exothermal reaction and stiffness of the cyanoacrylate adhesives is the increase of the length of the alkyl hydrocarbon chain.

To the best of our knowledge a comparison of the performance of suture versus ethyl, n-butyl and n-octyl cyanoacrylate adhesives for closing wounds in-vivo has not been carried out yet. Furthermore, the monitoring of haematological and biochemical tests in animals having skin wounds closed with cyanoacrylate adhesives of different alkyl chain

*Corresponding author: Angulo A, Optics, Pharmacology and Anatomy Department, University of Alicante, 03080 Alicante, Spain, Tel: +61424220219; E-mail: angulouaes@gmail.com

Received December 15, 2015; Accepted January 25, 2016; Published January 27, 2016.

Citation: Angulo A, Sebastián I, Martínez FJ, Torregrosa R, Martín-Martínez JM, et al. (2016) Comparative Effectiveness of Cyanoacrylate Bioadhesives and Monofilament Suture in Wound Healing: A Histopathological and Physicochemical Study in New Zealand White Rabbit. J Cytol Histol 7: 395. doi:10.4172/2157-7099.1000395

Copyright: ( 2016 Angulo A, et al. This is an open-access article distributed under the terms of the Creative Commons Attribution License, which permits unrestricted use, distribution, and reproduction in any medium, provided the original author and source are credited. 
Citation: Angulo A, Sebastián I, Martínez FJ, Torregrosa R, Martín-Martínez JM, et al. (2016) Comparative Effectiveness of Cyanoacrylate Bioadhesives and Monofilament Suture in Wound Healing: A Histopathological and Physicochemical Study in New Zealand White Rabbit. J Cytol Histol 7: 395. doi:10.4172/2157-7099.1000395

length has not been considered yet. Therefore, in this study, suture and three cyanoacrylate adhesives are used for skin wound closure in New Zealand White rabbits were carried out, paying particular attention to their physicochemical characterization and their performance in-vivo including histological, haematological and biochemical monitoring.

\section{Materials and Methods}

\section{Animals}

The study was performed under the terms of the previously existing Spanish Animal Protection Laws [13-15], European Directive [16] and approved by IACUC of the University of Alicante (Spain). Assays for medical device were conducted according to UNE-EN ISO 109931:2004 [17].

In the spirit of the 3 Rs, a reduced number of 36 New Zealand White rabbit males were used, 6 groups of 6 animals each one. Animals were purchased from National Production Centre (Granja San Bernardo, Navarra, Spain) and allowed to acclimatize for one week after arrival, the transport quarantine period. Rabbits were 8 weeks age at the moment of arrival, and had an average body weight of $1982.4 \mathrm{~g}$. The body weight was recorded weekly (the greater weight gain/week, average of $414.29 \mathrm{~g}$, occurred during the transport quarantine period).

Rabbits were maintained individually on a constant $12 \mathrm{hr}$ light/dark cycle, under controlled temperature $\left(22^{\circ} \pm 1.5^{\circ} \mathrm{C}\right)$ and relative humidity (55 $\pm 15 \%$ ), and 15 to 20 air renewal/hr (according to the European legislation). Rabbits were fed with 2030 Teklad Global Rabbit Diet (Harlan Laboratories, elaborated by Mucedola s.r.l., Italy) ad libitum. Water was softened by 4030 Dual Demand Softener (Ecowater Systems, Inc. USA) and freely accessible.

\section{Experimental Design}

\section{Biocompatibility study}

Blood samples were collected after vasodilation by rubbing of the marginal ear vein of the rabbits using $21 \mathrm{G} \mathrm{X1"} 0.8 \times 25 \mathrm{~mm}$ needle (Neolus, TERUMO, Leuven, Belgium). Blood collection needle was heparinised (Hospira 1\%, Rovi Laboratory, Madrid, Spain). Blood samples were collected at 3, 7, 8, 14, 21 and 28 day post-incision in the rabbits [18].

At each sampling time-point, $1 \mathrm{ml}$ blood was collected into collecting tubes containing ethylenediaminetetraacetic acid (EDTA) for haematological parameters measurement, i.e. white blood cell [WBC], lymphocytes, monocytes, granulocytes, lymphocytes \%, monocytes \%, granulocytes \%, blood cells, haemoglobin, haematocrit, mean cell volume, mean cell haemoglobin, mean cell haemoglobin concentration, red cell distribution width, platelets, mean platelet volume, and platelet cell distribution width. Abacus Haematology System Junior Vet (Diatron ${ }^{\circledR}, \mathrm{GmbH}$, Wien, Austria) was used.

In addition, blood samples $(1 \mathrm{ml})$ were collected into tubes containing Li Heparin. These samples were centrifuged at $2500 \mathrm{rpm}$ for 15 min in Centrifuge 5810R (Eppendorf, Hamburg, Germany) and the serum samples obtained were examined for the following parameters: albumin, alkaline phosphatase, alanine aminotransferase, amylase, total bilirubin, blood urea nitrogen, calcium, phosphorus, creatinine, glucose, sodium, potassium, total protein, globulin. Automatic analyzer VetScan (Union City, CA, USA) was used.

\section{Surgical method}

Animals were weighted and anaesthetized by intramuscular administration of Ketamine + Xylazine $(50+10 \mathrm{mg} / \mathrm{kg})$ (Imalgène
1000, Merial Laboratory, Barcelona, Spain + Xilagesic 2\%, Calier Laboratory, Barcelona, Spain). The whole procedure was performed on a sterile, clear, non-slippery, non-wrinkle surface and animals were placed in prone position. The lumbar region of the rabbit was shaved and disinfected with chlorhexidine (Lifo-Scrub, BIBRAUN, Melsungen, Germany). For comparing the influence of traction on the process of wound healing, two superficial incisions were made with a sterile surgical blade (Aesculap, BIBRAUN, Tuttlingen, Germany), one on each side of the lumbar region, $2 \mathrm{~cm}$ long, one longitudinal (L) and other transversal ( $\mathrm{T}$ ) to main axis of the animal body [19].

The wounds (incisions) were closured using monofilament suture (Dafilon, BIBRAUN, Tuttlingen, Germany) or with adhesive ethyl cyanocrylate $(\mathrm{ECN})$, butyl cyanocrylate $(\mathrm{BCN})$ or octyl cyanocrylate $(\mathrm{OCN})$. In the case of the adhesives, the wound edges were drawn and stretched longitudinally, applying the minimum amount of adhesive with a syringe. In the case of the suture, 5-6 points were performed (Figures 1A and 1B).

The closed wounds were bandaged in order to prevent further contamination and minimize the manipulation of the animal during healing process (Figures 1C and 1D). Animals received Meloxicam 0.1 $\mathrm{mg} / \mathrm{kg}$ p.o. (Metacam, Boehringer Laboratory, Ingelheim, Germany) in water for 48 hours to relieve pain and reduce inflammation.

Healing process was rated according to several clinical manifestations such as dehiscence, bleeding, infection, inflammation, and itching. Photographs were taken throughout the healing process with a digital camera Canon-Power-Shot-S45 (Canon Inc., Japan) in order to assess the degree of inflammation and tissue reaction (double blind observation). One semiobjective assessment in wound healing process in rabbit skin was applied. Each wound received an assessment from 1 (appalling) to 6 (excellent) according the parameters in Table 1.

\section{Cyanoacrylate adhesives}

Three cyanoacrylate adhesives were used in this study (Figure 2). Ethyl cyanoacrylate $(\mathrm{ECN})$ was prepared in the Adhesion and Adhesives Laboratory of the University of Alicante (Alicante, Spain). n-butyl cyanoacrylate (BCN) monomer was Vetbond manufactured by $3 \mathrm{M}$ (StPaul, Minnesota, USA) and contains hydroquinone stabilizer and blue dye. n-octyl cyanoacrylate (OCN) was Dermabond manufactured by Ethicon (Somerville, New Jersey, USA) and contains thickening agent, stabilizer and violet dye.

The structure of the cyanoacrylate adhesives was characterized by thermal gravimetric analysis (TGA). TGA studies were carried out in TA TGA Q500 instrument (TA instruments, New Castle, Delaware, USA) under nitrogen atmosphere (flow rate: $100 \mathrm{ml} / \mathrm{min}$ ). Samples of

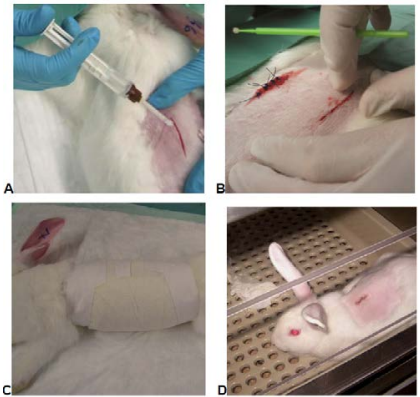

Figure 1: A) Application of the adhesive. B) Longitudinal incisions closed with sutures and adhesive. C) Placement of the dressing. D) Cage confinement and detachment of the dressing. 
Citation: Angulo A, Sebastián I, Martínez FJ, Torregrosa R, Martín-Martínez JM, et al. (2016) Comparative Effectiveness of Cyanoacrylate Bioadhesives and Monofilament Suture in Wound Healing: A Histopathological and Physicochemical Study in New Zealand White Rabbit. J Cytol Histol 7: 395. doi:10.4172/2157-7099.1000395

Page 3 of 8

\begin{tabular}{|c|c|c|c|c|c|c|c|}
\hline $\begin{array}{l}\text { Macroscopic and } \\
\text { microscopic criteria }\end{array}$ & 1=Appalling & 2=Very bad & $3=$ Wrong & 4=Well & $5=$ Very well & 6=Excellent & $\begin{array}{l}0=\text { Without } \\
\text { sample }\end{array}$ \\
\hline $\begin{array}{l}\text { Degree of separation } \\
\text { of the edges of the } \\
\text { surgical incision } \\
\text { wound }\end{array}$ & $\begin{array}{c}\text { Open wound edges } \\
\text { with wide separation } \\
\text { from the surface to } \\
\text { the bottom }\end{array}$ & $\begin{array}{l}\text { Open wound } \\
\text { edges more } \\
\text { separated in the } \\
\text { surface and less } \\
\text { at the bottom }\end{array}$ & $\begin{array}{c}\text { Open wound } \\
\text { closely spaced } \\
\text { in the surface } \\
\text { and joined at the } \\
\text { bottom }\end{array}$ & $\begin{array}{l}\text { Closed wound } \\
\text { without separated } \\
\text { edges from the } \\
\text { surface to the } \\
\text { bottom }\end{array}$ & $\begin{array}{l}\text { Closed wound } \\
\text { without separated } \\
\text { edges from the } \\
\text { surface to the } \\
\text { bottom }\end{array}$ & $\begin{array}{c}\text { Closed wound } \\
\text { without separated } \\
\text { edges from the } \\
\text { surface to the bottom }\end{array}$ & \multirow{7}{*}{$\begin{array}{l}\text { Histological } \\
\text { sections of the } \\
\text { sample have } \\
\text { not been able } \\
\text { to obtain due } \\
\text { to problems in } \\
\text { processing (e.g. } \\
\text { the paraffin could } \\
\text { not penetrate into } \\
\text { tissue cells, tissue } \\
\text { hardening due } \\
\text { to the adhesive } \\
\text { that prevented } \\
\text { obtaining sections, } \\
\text { sections with } \\
\text { broken tissue or } \\
\text { undone, etc.) }\end{array}$} \\
\hline $\begin{array}{l}\text { Presence of residual } \\
\text { clot or scab dead } \\
\text { cells between the } \\
\text { edges of the wound or } \\
\text { superficial }\end{array}$ & $\begin{array}{l}\text { With abundant } \\
\text { remains of clot or } \\
\text { scab }\end{array}$ & $\begin{array}{c}\text { With abundant to } \\
\text { moderate remains } \\
\text { of clot or scab }\end{array}$ & $\begin{array}{c}\text { With moderate to a } \\
\text { few remains of clot } \\
\text { or scab }\end{array}$ & $\begin{array}{c}\text { Scarce or no } \\
\text { remains of clot or } \\
\text { scab }\end{array}$ & $\begin{array}{l}\text { No remains of clot } \\
\text { or scab }\end{array}$ & $\begin{array}{l}\text { No remains of clot } \\
\quad \text { or scab }\end{array}$ & \\
\hline $\begin{array}{l}\text { Traces of adhesive } \\
\text { between the edges } \\
\text { of the wound or } \\
\text { superficial }\end{array}$ & $\begin{array}{l}\text { With abundant } \\
\text { remains of adhesive }\end{array}$ & $\begin{array}{c}\text { With abundant to } \\
\text { moderate remains } \\
\text { of adhesive }\end{array}$ & $\begin{array}{c}\text { With moderate to } \\
\text { a few remains of } \\
\text { adhesive }\end{array}$ & $\begin{array}{l}\text { Scarce or no } \\
\text { adhesive residue }\end{array}$ & No adhesive residue & No adhesive residue & \\
\hline $\begin{array}{l}\text { Degree of } \\
\text { inflammatory reaction/ } \\
\text { redness (presence of } \\
\text { abundant leukocytes) }\end{array}$ & $\begin{array}{l}\text { Very intense } \\
\text { inflammation }\end{array}$ & $\begin{array}{l}\text { Very intense } \\
\text { to intense } \\
\text { inflammation }\end{array}$ & $\begin{array}{l}\text { Intense to } \\
\text { moderate } \\
\text { inflammation }\end{array}$ & $\begin{array}{c}\text { Moderate } \\
\text { to scarce } \\
\text { inflammation }\end{array}$ & $\begin{array}{c}\text { Without inflammation } \\
\text { or very low }\end{array}$ & $\begin{array}{l}\text { No trace of } \\
\text { inflammatory } \\
\text { reaction }\end{array}$ & \\
\hline $\begin{array}{l}\text { Degree of fibrotic } \\
\text { scar line (presence of } \\
\text { collagen fibers) in the } \\
\text { junction area of the } \\
\text { edges of the wound } \\
\text { and its immediate } \\
\text { reaction }\end{array}$ & $\begin{array}{l}\text { Low, moderate, or } \\
\text { severe fibrosis }\end{array}$ & $\begin{array}{l}\text { Moderate or } \\
\text { severe fibrosis }\end{array}$ & $\begin{array}{l}\text { Moderate or } \\
\text { severe fibrosis }\end{array}$ & $\begin{array}{l}\text { Moderate or } \\
\text { severe fibrosis }\end{array}$ & $\begin{array}{l}\text { Low to moderate } \\
\text { fibrosis }\end{array}$ & $\begin{array}{l}\text { Absence or very little } \\
\text { fibrosis }\end{array}$ & \\
\hline Healing type & \multicolumn{3}{|c|}{$\begin{array}{l}\text { Secondary closure: epidermal re-epithelialisation from the } \\
\text { bottom of the wound due to failure at the junction of its edges }\end{array}$} & \multicolumn{3}{|c|}{$\begin{array}{l}\text { Primaryclosure: epidermal resurfacing on the surface of the } \\
\text { wound due to successful union of its edges }\end{array}$} & \\
\hline $\begin{array}{l}\text { Degree of recovery of } \\
\text { normal tissue from the } \\
\text { junction of the edges of } \\
\text { the wound and adjacent }\end{array}$ & $\begin{array}{c}\text { Unrecovered skin in } \\
\text { the joint and adjacent } \\
\text { area }\end{array}$ & $\begin{array}{c}\text { Unrecovered skin } \\
\text { in the joint and } \\
\text { adjacent area }\end{array}$ & $\begin{array}{c}\text { Unrecovered skin } \\
\text { in the joint and } \\
\text { adjacent area }\end{array}$ & $\begin{array}{l}\text { Partially } \\
\text { recovered skin } \\
\text { in the joint and } \\
\text { adjacent area }\end{array}$ & $\begin{array}{l}\text { Almost normal- } \\
\text { looking skin in the } \\
\text { joint and adjacent } \\
\text { area }\end{array}$ & $\begin{array}{l}\text { Almost normal- } \\
\text { looking skin in the } \\
\text { joint and adjacent } \\
\text { area }\end{array}$ & \\
\hline
\end{tabular}

Table 1: Healing evaluation procedure criteria used for assessing the degree of inflammation and tissue reaction under macroscopic and microscopic.



Figure 2: Structure of the cyanoacrylates used in this study: ethyl cyanoacrylate (ECN: $\left.\mathrm{R}=\mathrm{CH}_{2}-\mathrm{CH}_{3}\right)$, n-butyl cyanoacrylate $\left(\mathrm{BCN}\right.$ : $\left.\mathrm{R}=\left(\mathrm{CH}_{2}\right)_{3}-\mathrm{CH}_{3}\right)$ and n-octyl cyanoacrylate $\left(\mathrm{OCN}: \mathrm{R}=\left(\mathrm{CH}_{2}\right)_{7}-\mathrm{CH}_{3}\right)$.
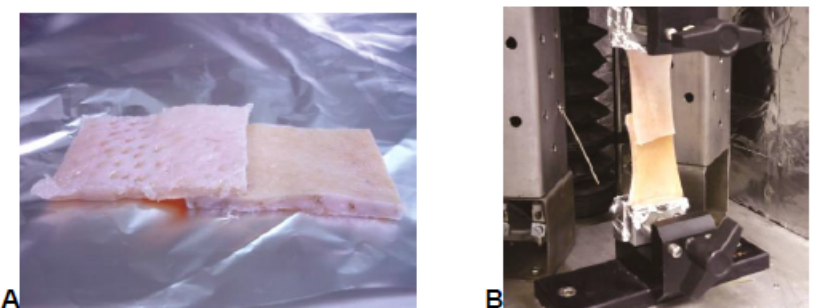

Figure 3: A) Pig skin/cyanoacrylate adhesive/pig skin joint used in single lap-shear tests.

B) Single lap-shear test of pig skin/cyanoacrylate adhesive/pig skin joint.

cyanoacrylate $(10-15 \mathrm{mg})$ were heated from room temperature up to $400^{\circ} \mathrm{C}$ by using a heating rate of $10^{\circ} \mathrm{C} / \mathrm{min}$.

\section{In vitro adhesion studies in pig skin/adhesive joints}

The immediate adhesion was determined by single lap-shear tests of pig skin/cyanoacrylate adhesive/pig skin joints. Pig skin was used as a model for skin of rabbit. Pig skin test samples of dimensions $60 \times 30 \mathrm{~mm}$ were cut from the upper leg pieces of freshly sacrificed pig (supplied by Juan Carlos Lillo Garrigós' butcher shop, San Vicente del
Raspeig, Alicante, Spain). The pig skin test samples were immersed for 5 minutes in $60 \mathrm{ml}$ physiological serum solution (Fleboplast, Grifols, Barcelona, Spain) to impart homogeneous and controlled humidity. 10 seconds after removal of the test pieces from the solution, they were surface dried with filter paper for 10 seconds and the test samples were maintained under ambient conditions for 30 seconds.

$0.05 \mathrm{ml}$ of cyanoacrylate adhesive was applied by means of a syringe on one pig skin test piece and the adhesive was spread over a bonding area of $20 \times 30 \mathrm{~mm}$ by means of the syringe needle. The second test piece was immediately placed in contact and press by using two fingers for 30 seconds (Figure $3 \mathrm{~A}$ ). 60 seconds later, the single lap-shear test was carried out in Instron 4411 universal testing machine (Instron Ldt. Buckinghamshire, UK) by using a pulling rate of $100 \mathrm{~mm} / \mathrm{min}$ (Figure $3 \mathrm{~B})$. Five replicates were measured and averaged.

\section{Histopathological method}

Animals .were sacrificed with an overdose of pentobarbital i.v. (Dolethal, Vétoquinol, Cedex, France). Two skin samples of dimensions $2 \times 1 \times 0.3 \mathrm{~cm}$ approximately were collected from each rabbit and they were placed in a container with formalin $10 \%$ (Formaldehyde 37-38\%w/w, Panreac, Barcelona, Spain) for 6 hours at least; the volume of formalin was threefold higher than the size of the skin samples.

Skin samples were removed from formalin and processed by conventional histological embedded paraffin (Histosec pastilles, Merck, Darmstadt, Germany) method. The paraffin blocks with the samples were cut perpendicularly to the skin surface in $10-15 \mu \mathrm{m}$ histological sections using automatic microtome Leica-RM-2065 (Wetzlar, Germany). Each sample was spread on glycerinated albumin slide with distilled water at $35-40^{\circ} \mathrm{C}$, followed by dewaxing, rehydration, 
Citation: Angulo A, Sebastián I, Martínez FJ, Torregrosa R, Martín-Martínez JM, et al. (2016) Comparative Effectiveness of Cyanoacrylate Bioadhesives and Monofilament Suture in Wound Healing: A Histopathological and Physicochemical Study in New Zealand White Rabbit. J Cytol Histol 7: 395. doi:10.4172/2157-7099.1000395

staining and dehydration. Haematoxylin and eosin-stained sections were examined with transmitted light microscope (Leica DMLS) and photomicrographs were taken with digital camera. Samples were reevaluated according the parameters of the Table 1.

\section{Results and Discussion}

In this section, the structure of the cyanoacrylate monomers with different alkyl hydrocarbon length was analyzed by TGA and their inherent immediate in-vitro adhesion was measured by single lap-shear strength tests of pig skin/cyanoacrylate adhesive/pig skin joints. In the third part of this section, the haematological and histopathological features of wounds made in rabbits which were healed with suture and different cyanoacrylate adhesives was carried out.

\section{Structural characterization of the cyanoacrylate monomers}

In this study TGA was found useful and sensitive to analyze the structure of the cyanoacrylate adhesives. Figure $4 \mathrm{~A}$ shows the variation of the weight loss as a function of the temperature (TGA thermograms) of the three cyanoacrylate adhesives and the corresponding derivative curves are given in Figure 4B; the derivative curves are useful for showing more precisely the thermal decompositions in the cyanoacrylates which correspond to different structures.

The TGA thermograms of the three cyanoacrylate monomers show the first decomposition at about $120^{\circ} \mathrm{C}$ (Table 2), likely due to formaldehyde evolution. This first decomposition becomes less marked by increasing the length of the alkyl hydrocarbon chain of the cyanoacrylate, i.e. the weight loss at this temperature decreases from ethyl to n-octyl cyanoacrylate. On the other hand, the lowest thermal stability corresponds to the ethyl cyanoacrylate and the highest one to the n-octyl cyanoacrylate.

The presence of more than one decomposition step in the cyanoacrylate monomers is an indication of the presence of oligomers in their structure. Whereas the ethyl cyanoacrylate is mainly composed of monomer $\left(98.7 \mathrm{wt} \%\right.$ is lost at $\left.117^{\circ} \mathrm{C}\right)$, the n-butyl cyanoacrylate contains monomer and some dimmers $\left(17.8 \mathrm{wt} \%\right.$ is lost at $\left.157^{\circ} \mathrm{C}\right)$, and the n-octyl cyanoacrylate has only a minor content of monomer (only $25.3 \mathrm{wt} \%$ is lost at $126^{\circ} \mathrm{C}$ ) and shows four additional decompositions (Figure 4 and Table 2). These results are in agreement with literature [20] that also described the existence of different decompositions in the TGA thermograms of n-butyl cyanoacrylate polymer ascribed to

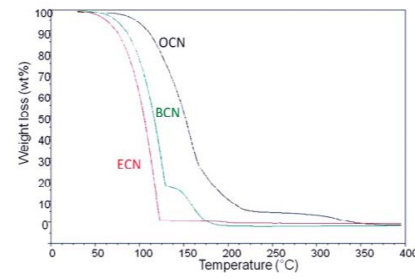

$\mathbf{A}$

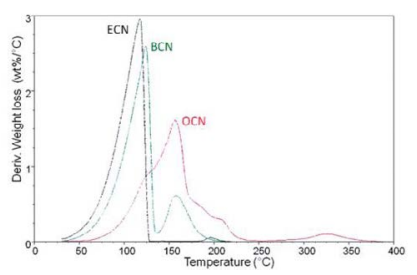

B
Figure 4: Variation of A) The weight loss and B) The derivative of the weight loss as a function of the temperature of the cyanoacrylate monomers. the existence of different structures in the polymer. As a consequence, the structural heterogeneity of the cyanoacrylate monomers becomes more marked by increasing their alkyl hydrocarbon chain length likely due to slower kinetics of reaction. This issue may affect the time for polymerization of the cyanoacrylate adhesive on the wound in the rabbit skin. Therefore, the immediate adhesion of the cyanoacrylate adhesives was tested.

\section{Immediate adhesion of the cyanoacrylate adhesives}

The immediate adhesion (i.e., 60 seconds after joint formation) of the cyanoacrylate adhesives was measured by single lap-shear tests of pig skin/cyanoacrylate adhesive/pig skin joints as an estimation of their performance in wound closure. Figure 5 shows the adhesive strength values of the pig skin/cyanoacrylate adhesive joints and, in general, it decreases by increasing the length of the alkyl hydrocarbon chain of the cyanoacrylate adhesive. The adhesive strength values obtained in the joints made with ethyl and n-butyl cyanoacrylate are high and sufficient to maintain the tissues joined in wound closure.

\section{Haematological and histopathological features of wound healing in rabbit skin by using suture and cyanoacrylate adhesives}

Most biochemical parameters analyzed and haemogram (Tables 3 and 4) are within the normal range given by the different references for rabbits [1], with a marked increase until 12 weeks of age, associated with higher growth and body weight gain, except calcium and phosphorus that decreases with decreasing growth and bone metabolism.

Total protein are in the normal range and increase with age, from 5.23 to $5.92 \mathrm{~g} / \mathrm{dL}$ although the albumin gives low values, from 1.64 to $2.14 \mathrm{~g} / \mathrm{dL}$, an increase of $0.48 \mathrm{~g} / \mathrm{dL}$, however, globulin has high levels of 3.57 to $3.78 \mathrm{~g} / \mathrm{dL}$, a smaller increase, $0.21 \mathrm{~g} / \mathrm{dL}$. Alkaline phosphatase increased significantly up to 12 weeks old, 115 to $162.78 \mathrm{IU} / \mathrm{L}$, and then decreases gradually. The amylase gave low levels throughout the study, although gradually increase along this, of from 122.75 to $160.2 \mathrm{IU} / \mathrm{L}$, reference values in the literature are from 200 to $500 \mathrm{IU} / \mathrm{L}$. The literature associates the low level of some parameters with the confinement in cages and the lack or poor caecotrophy, a physiological mechanism of the rabbit.

The white blood cells (WBC), the highest value is observed at 12 weeks of age, $8,67 \times 109 / \mathrm{L}$, and the ratio lymphocyte / granulocyte in this age, is of $30 / 60$ as the literature points reference.

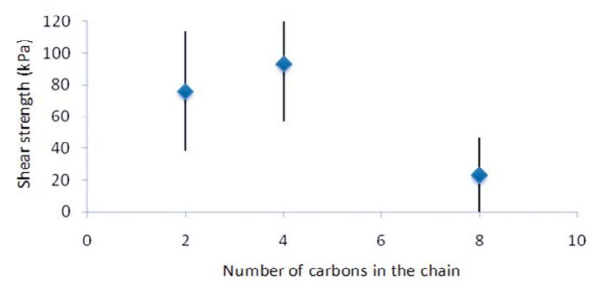

Figure 5: Single lap-shear strength values of pig skin/cyanoacrylate adhesive/ pig skin adhesive joints. Values obtained 60 seconds after joint formation. A mixed failure (cohesive in the adhesion and adhesion to pig skin) was obtained in all adhesive joints.

\begin{tabular}{|c|c|c|c|c|c|c|c|c|c|c|}
\hline Monomer & $\mathrm{T} 1\left({ }^{\circ} \mathrm{C}\right)$ & $\begin{array}{c}\text { Weight loss1 } \\
\text { (wt\%) }\end{array}$ & $\mathrm{T} 2\left({ }^{\circ} \mathrm{C}\right)$ & $\begin{array}{l}\text { Weight loss2 } \\
\text { (wt\%) }\end{array}$ & $\mathrm{T} 3\left({ }^{\circ} \mathrm{C}\right)$ & $\begin{array}{l}\text { Weight loss3 } \\
\text { (wt\%) }\end{array}$ & $\mathrm{T} 4\left({ }^{\circ} \mathrm{C}\right)$ & $\begin{array}{l}\text { Weight loss } 4 \\
\text { (wt\%) }\end{array}$ & $\mathrm{T} 5\left({ }^{\circ} \mathrm{C}\right)$ & $\begin{array}{c}\text { Weight loss5 } \\
\text { (wt \%) }\end{array}$ \\
\hline ECN & 117 & 98.7 & - & - & - & - & 196 & 1.3 & - & - \\
\hline $\mathrm{BCN}$ & 124 & 83.9 & 157 & 17.8 & - & - & - & - & - & - \\
\hline OCN & 126 & 25.3 & 156 & 48.2 & 175 & 13.5 & 208 & 7.1 & 327 & 5.9 \\
\hline
\end{tabular}

Table 2: Weight loss and temperature of the thermal decompositions of the cyanoacrylate monomers: TGA experiments. 
Citation: Angulo A, Sebastián I, Martínez FJ, Torregrosa R, Martín-Martínez JM, et al. (2016) Comparative Effectiveness of Cyanoacrylate Bioadhesives and Monofilament Suture in Wound Healing: A Histopathological and Physicochemical Study in New Zealand White Rabbit. J Cytol Histol 7: 395. doi:10.4172/2157-7099.1000395

Page 5 of 8

\begin{tabular}{|c|c|c|c|c|c|c|c|c|c|c|c|c|c|c|c|}
\hline \multirow{2}{*}{$\begin{array}{c}\text { Age } \\
\text { (weeks) }\end{array}$} & \multirow{2}{*}{ n } & \multicolumn{2}{|c|}{ ALB } & \multicolumn{2}{|c|}{ TP } & \multicolumn{2}{|c|}{ GLOB } & \multicolumn{2}{|c|}{ ALP } & \multicolumn{2}{|c|}{ ALT } & \multicolumn{2}{|c|}{ AMYL } & \multicolumn{2}{|c|}{ TBIL } \\
\hline & & (g/dl) & range & $(g / d l)$ & range & $(g / d l)$ & range & (IU/L) & range & (IU/L) & range & (IU/L) & range & (mg/dl) & range \\
\hline 9 & 18 & 1.64 & $1.1-1.9$ & 5.23 & $4.4-6.1$ & 3.57 & $3.1-4.4$ & 115 & $80-179$ & 38.58 & $25-61$ & 122.75 & $93-164$ & 0.2 & 0.2 \\
\hline 10 & 12 & 1.7 & $1.1-2$ & 5.34 & $4.4-6.2$ & 3.59 & 2.9-5.1 & 127.36 & $67-170$ & 40 & $29-52$ & 128.73 & $55-180$ & 0.15 & $0.1-0.2$ \\
\hline 11 & 20 & 1.96 & $1.4-2.3$ & 5.61 & $4.9-6.3$ & 3.64 & $3.2-4.2$ & 144.75 & $92-207$ & 40.1 & $31-55$ & 153.6 & $85-216$ & 0.19 & $0.1-0.2$ \\
\hline 12 & 14 & 2.14 & $2.2-3$ & 5.72 & $5.2-6.3$ & 3.58 & $3.2-4.1$ & 162.79 & $119-222$ & 38.57 & $30-54$ & 149.71 & $74-185$ & 0.18 & $0.1-0.2$ \\
\hline 13 & 12 & 2.02 & $1.7-2.2$ & 5.82 & $5.2-6.3$ & 3.83 & $3.5-4.2$ & 138.36 & $89-203$ & 43.64 & $30-56$ & 137.36 & $94-180$ & 0.18 & $0.1-0.2$ \\
\hline 14 & 10 & 2.05 & $1.8-2.2$ & 5.86 & $5.5-6.4$ & 3.75 & $3.3-4.3$ & 134.4 & $89-253$ & 39 & $20-51$ & 148.2 & $68-189$ & 0.17 & $0.1-0.3$ \\
\hline 15 & 5 & 2.12 & $1.8-2.2$ & 5.92 & 5.4-6.4 & .78 & 3.3-4.1 & 112.6 & $92-146$ & 42.4 & $27-56$ & 160.2 & $126-190$ & 0.2 & 0.2 \\
\hline \multirow{2}{*}{$\begin{array}{c}\text { Age } \\
\text { (weeks) }\end{array}$} & \multirow{2}{*}{$\mathrm{n}$} & \multicolumn{2}{|c|}{ BUN } & \multicolumn{2}{|c|}{$\mathrm{Ca}^{++}$} & \multicolumn{2}{|c|}{$\mathbf{P}$} & \multicolumn{2}{|c|}{ CRE } & \multicolumn{2}{|c|}{ GLU } & \multicolumn{2}{|c|}{$\mathrm{Na}^{+}$} & \multicolumn{2}{|c|}{$\kappa$} \\
\hline & & (mg/dl) & range & (mg/dl) & range & (mg/dl) & range & (mg/dl) & range & range & (mg/dl) & range & $(\mathrm{mg} / \mathrm{dl})$ & range & $(\mathrm{mg} / \mathrm{dl})$ \\
\hline 9 & 18 & 10.83 & 7.0-14 & 15.98 & $15.8-16$ & 6.92 & 6.1-7.8 & 0.45 & 10.83 & $7.0-14$ & 15.98 & |15.8-16 & 6.92 & $6.1-7.8$ & 0.45 \\
\hline 10 & 12 & 12.09 & $10.0-14$ & 16.06 & $\begin{array}{l}15.4- \\
17.4\end{array}$ & 6.13 & $4.8-7.3$ & 0.46 & 12.09 & 10.0-14 & 16.06 & $15.4-17.4$ & 6.13 & $4.8-7.3$ & 0.46 \\
\hline 11 & 20 & 13.9 & $10.0-18.0$ & 15.87 & 14.7-16 & 7.09 & $6.2-8$ & 0.56 & 10.5 & $10.0-18.0$ & 15.87 & $14.7-16$ & 7.09 & $6.2-8$ & 0.56 \\
\hline 12 & 14 & 14.78 & $9.0-19.0$ & 15.61 & $14.7-16$ & 6.77 & $5.7-8.3$ & 0.63 & 14.78 & $9.0-19.0$ & 15.61 & $14.7-16$ & 6.77 & $5.7-8.3$ & 0.63 \\
\hline 13 & 12 & 15.64 & $12.0-19.0$ & 15.67 & $\begin{array}{c}14.2- \\
16.5\end{array}$ & 6.36 & $6-7.2$ & 0.58 & 15.64 & $12.0-19.0$ & 15.67 & $14.2-16.5$ & 6.36 & $6-7.2$ & 0.58 \\
\hline 14 & 10 & 15 & $12.0-19.0$ & 15.11 & $14-17.2$ & 6.29 & $4.9-7.9$ & 0. & 13 & $12.0-19.0$ & 15.11 & $14-17.2$ & 6.29 & $4.9-7.9$ & 0.6 \\
\hline 15 & 5 & 16.6 & $13-20$ & 15.12 & 14.4-16 & 6.38 & $5.6-7$ & 0.64 & 16.6 & $13-20$ & 15.12 & $14.4-16$ & 6.38 & $5.6-7$ & 0.64 \\
\hline
\end{tabular}

Table 3: Blood biochemical parameters results of New Zealand White rabbits $(n=$ number of animals). ALB: Albumin, TP: Total Protein, GLOB: Globuline, ALP: Alkaline Phosphatase, ALT: Alanine Transaminase, AMYL: Amylase, TBIL: Total Bilirubin, BUN: Blood Urea Nitrogen, Ca ${ }^{++}$: Calcium, P: Phosphorus, CRE: Creatinine, GLU: Glucose $\mathrm{Na}^{+}$: Sodium, $\mathrm{K}^{+}$: Potassium.

\begin{tabular}{|c|c|c|c|c|c|c|c|c|c|c|c|c|c|c|c|c|c|c|c|}
\hline \multicolumn{2}{|c|}{$\begin{array}{c}\text { Age } \\
\text { (weeks) }\end{array}$} & \multirow{2}{*}{$\begin{array}{c}n \\
\left(10^{\wedge} 9 / L\right)\end{array}$} & \multicolumn{3}{|c|}{ WBC } & \multirow{2}{*}{\begin{tabular}{|l|} 
LYM \\
range \\
\end{tabular}} & \multicolumn{2}{|c|}{ MID } & \multicolumn{2}{|c|}{ GRA } & \multicolumn{2}{|c|}{ LYM } & \multicolumn{2}{|c|}{ MID } & GRA & \multicolumn{2}{|c|}{ RBC } & \multicolumn{2}{|c|}{ HGB } \\
\hline$\left(10^{\wedge} 9 / L\right)$ & range & & range & \multicolumn{2}{|c|}{ (10^9/L) } & & (10^9/L) & range & (\%) & \multicolumn{2}{|c|}{ range } & $(\%)$ & range & $(\%)$ & range & $\left(10^{\wedge} 12 / L\right)$ & range & (g/dl) & range \\
\hline 9 & 18 & 7.14 & $\begin{array}{c}3.63- \\
13.6\end{array}$ & 5.13 & $\begin{array}{l}1.13- \\
10.8\end{array}$ & 0.18 & $\begin{array}{l}0.04- \\
0.62\end{array}$ & 2.99 & $\begin{array}{l}0.56- \\
7.03\end{array}$ & 62.67 & $\begin{array}{l}16.8- \\
85.6\end{array}$ & 1.95 & $0.6-3.9$ & 35.38 & $\begin{array}{l}12.7- \\
82.6\end{array}$ & 6.22 & $3.46-7.29$ & 10.94 & $\begin{array}{l}6.3- \\
13.1\end{array}$ \\
\hline 10 & 12 & 8.55 & $\begin{array}{c}5.89- \\
11.7\end{array}$ & 6.77 & $\begin{array}{c}3.54- \\
8.89\end{array}$ & 0.25 & $\begin{array}{l}0.07- \\
0.58\end{array}$ & 2.21 & $\begin{array}{l}0.7- \\
4.1\end{array}$ & 74.32 & $\begin{array}{l}\text { 63.4- } \\
86.3\end{array}$ & 2.85 & $0.9-8.7$ & 22.84 & $\begin{array}{l}12.6- \\
32.8\end{array}$ & 6.58 & $4.87-7.42$ & 11.48 & $\begin{array}{l}8.2- \\
13.4\end{array}$ \\
\hline 11 & 20 & 6.65 & $\begin{array}{c}0.77- \\
10.4\end{array}$ & 3.42 & $\begin{array}{l}0.62- \\
8.54\end{array}$ & 0.01 & $0-0.36$ & 1.97 & \begin{tabular}{|l|}
$0.19-$ \\
10.3
\end{tabular} & 69.94 & \begin{tabular}{|l|}
$11.1-$ \\
96.5
\end{tabular} & 1.37 & $0.4-3.6$ & 29.37 & $\begin{array}{l}14.6- \\
88.2\end{array}$ & 5.75 & $1.41-7.89$ & 10.63 & $\begin{array}{l}2.4- \\
16.1\end{array}$ \\
\hline 12 & 14 & 8.66 & \begin{tabular}{|l|}
$6.07-$ \\
12.7
\end{tabular} & 7.16 & $\begin{array}{l}5.39- \\
9.41\end{array}$ & 0.17 & $\begin{array}{l}0.07- \\
0.41\end{array}$ & 2.43 & $\begin{array}{l}1.26- \\
5.53\end{array}$ & 74.01 & $\begin{array}{l}62.3- \\
84.9\end{array}$ & 1.75 & $0.7-3.5$ & 24.24 & $\begin{array}{c}11.6- \\
37\end{array}$ & 6.51 & $5.73-7.36$ & 11.89 & $\begin{array}{l}10.5- \\
12.6\end{array}$ \\
\hline 13 & 12 & 7.97 & $\begin{array}{c}5.78- \\
11.9\end{array}$ & 6.54 & $\begin{array}{l}0.87- \\
9.83\end{array}$ & 0.22 & $\begin{array}{l}0.04- \\
0.68\end{array}$ & 2.52 & \begin{tabular}{|l|}
$0.49-$ \\
8.19
\end{tabular} & 71.53 & $\begin{array}{l}9.5- \\
91.2\end{array}$ & 2.39 & $0.5-8.4$ & 26.07 & $\begin{array}{l}7.1- \\
89.9\end{array}$ & 6.89 & $6.24-8.26$ & 12.37 & $\begin{array}{l}11.3- \\
13.6\end{array}$ \\
\hline 14 & 10 & 7.87 & $\begin{array}{c}4.53- \\
10.7\end{array}$ & 6.76 & $\begin{array}{c}0.42- \\
10.5\end{array}$ & 0.27 & $\begin{array}{l}0.04- \\
0.73\end{array}$ & 2.12 & $\begin{array}{l}0.62- \\
6.08\end{array}$ & 72.01 & $\begin{array}{l}6.4- \\
86.6\end{array}$ & 2.95 & $0.7-6.9$ & 17.49 & $\begin{array}{l}11.8- \\
37.7\end{array}$ & 6.86 & $5.9-7.52$ & 12.44 & $\begin{array}{l}11.8- \\
13.3\end{array}$ \\
\hline 15 & 5 & 8.45 & $\begin{array}{l}6.6- \\
10.7\end{array}$ & 7.66 & $\begin{array}{l}5.8- \\
10.3\end{array}$ & 0.37 & $\begin{array}{l}0.04- \\
0.84\end{array}$ & 1.61 & \begin{tabular}{|l|}
$1.16-$ \\
2.41
\end{tabular} & 79.12 & $\begin{array}{l}72.7- \\
84.6\end{array}$ & 3.82 & $0.5-10$ & 17.08 & $\begin{array}{c}10- \\
22.3\end{array}$ & 6.78 & $6.28-7.09$ & 12.64 & $\begin{array}{l}12.3- \\
12.9\end{array}$ \\
\hline \multicolumn{2}{|c|}{$\begin{array}{c}\text { Age } \\
\text { (weeks) }\end{array}$} & $\mathbf{n}$ & \multicolumn{3}{|c|}{ HCT } & MCV & \multicolumn{2}{|c|}{$\mathrm{MCH}$} & \multicolumn{2}{|c|}{ МСHC } & \multicolumn{2}{|c|}{ RDWc } & \multicolumn{2}{|c|}{ PLT } & РСТ & \multicolumn{2}{|c|}{ MPV } & \multicolumn{2}{|c|}{ PDWc } \\
\hline$(\%)$ & range & (fl) & range & (pg) & \multicolumn{2}{|c|}{ range } & (g/dl) & range & $(\%)$ & $(\%)$ & range & (fl) & \multicolumn{2}{|c|}{ range } & (pg) & range & (g/dl) & range & $(\%)$ \\
\hline 9 & 18 & 37.68 & $\begin{array}{c}22.5- \\
46\end{array}$ & 60.92 & $57-65$ & 17.61 & $\begin{array}{l}16.3- \\
18.4\end{array}$ & 28.96 & \begin{tabular}{|c|}
$27.8-$ \\
31.2
\end{tabular} & 13.83 & 37.68 & $\begin{array}{c}22.5- \\
46\end{array}$ & 60.92 & $57-65$ & 17.61 & $16.3-18.4$ & 28.96 & $\begin{array}{l}27.8- \\
31.2\end{array}$ & 13.83 \\
\hline 10 & 12 & 39.29 & $\begin{array}{l}28.2- \\
46.9\end{array}$ & 59.83 & $56-63$ & 17.43 & $\begin{array}{l}16.3- \\
18.6\end{array}$ & 29.18 & \begin{tabular}{|l|}
$28.5-$ \\
29.7
\end{tabular} & 14.02 & 39.29 & $\begin{array}{l}28.2- \\
46.9\end{array}$ & 59.83 & $56-63$ & 17.43 & 16.3-18.6 & 29.18 & $\begin{array}{l}28.5- \\
29.7\end{array}$ & 14.02 \\
\hline 11 & 20 & 32.35 & \begin{tabular}{|l|}
$8.47-$ \\
49.4
\end{tabular} & 56.8 & $46-65$ & 18.45 & $\begin{array}{l}17.2- \\
20.5\end{array}$ & 32.91 & \begin{tabular}{|l|}
$28.6-$ \\
40.1
\end{tabular} & 13.75 & 32.35 & $\begin{array}{l}8.47- \\
49.4\end{array}$ & 56.8 & $46-65$ & 18.45 & $17.2-20.5$ & 32.91 & $\begin{array}{c}28.6- \\
40.1\end{array}$ & 13.75 \\
\hline 12 & 14 & 36.36 & $\begin{array}{l}31.5- \\
41.3\end{array}$ & 56.07 & $51-60$ & 18.33 & $\begin{array}{l}16.8- \\
20.5\end{array}$ & 32.76 & \begin{tabular}{|l|}
$29.6-$ \\
34.7
\end{tabular} & 14.71 & 36.36 & $\begin{array}{l}31.5- \\
41.3\end{array}$ & 56.07 & $51-60$ & 18.33 & $16.8-20.5$ & 32.76 & $\begin{array}{l}29.6- \\
34.7\end{array}$ & 14.71 \\
\hline 13 & 12 & 7.97 & $\begin{array}{c}5.78- \\
11.9\end{array}$ & 6.54 & $\begin{array}{l}0.87- \\
9.83\end{array}$ & 0.22 & $\begin{array}{l}0.04- \\
0.68\end{array}$ & 2.52 & \begin{tabular}{|l|}
$0.49-$ \\
8.19
\end{tabular} & 71.53 & $\begin{array}{l}9.5- \\
91.2\end{array}$ & 2.39 & $0.5-8.4$ & 26.07 & $\begin{array}{l}7.1- \\
89.9\end{array}$ & 6.89 & $6.24-8.26$ & 12.37 & $\begin{array}{l}11.3- \\
13.6\end{array}$ \\
\hline 14 & 10 & 7.87 & $\begin{array}{c}4.53- \\
10.7\end{array}$ & 6.76 & $\begin{array}{c}0.42- \\
10.5\end{array}$ & 0.27 & $\begin{array}{l}0.04- \\
0.73\end{array}$ & 2.12 & $\begin{array}{l}0.62- \\
6.08\end{array}$ & 72.01 & $\begin{array}{l}6.4- \\
86.6\end{array}$ & 2.95 & $0.7-6.9$ & 17.49 & $\begin{array}{l}11.8- \\
37.7\end{array}$ & 6.86 & 5.9-7.52 & 12.44 & $\begin{array}{l}11.8- \\
13.3\end{array}$ \\
\hline 15 & 5 & 8.45 & $\begin{array}{l}6.6- \\
10.7\end{array}$ & 7.66 & $\begin{array}{l}5.8- \\
10.3\end{array}$ & 0.37 & $\begin{array}{l}0.04- \\
0.84\end{array}$ & 1.61 & \begin{tabular}{|l|}
$1.16-$ \\
2.41
\end{tabular} & 79.12 & $\begin{array}{l}72.7- \\
84.6\end{array}$ & 3.82 & $0.5-10$ & 17.08 & $\begin{array}{c}10- \\
22.3\end{array}$ & 6.78 & $6.28-7.09$ & 12.64 & 12.3- \\
\hline
\end{tabular}

Table 4: Haemogram results of New Zealand White rabbits ( $n=$ number of animals). WBC: White Blood Cells, LYM: Lymphocyte, MID: Mid-Sized Cells, GRA: Granulocyte, RBC: Red Blood Cells, HGB: Haemoglobin, HCT: Haematocrit, MCV: Mean Corpuscular Volume, MCH: Mean Corpuscular Haemoglobin, MCHC: Mean Corpuscular Haemoglobin Concentration, RDWc: Red Cell Distribution Width, PLT: Platelets, PCT: Relative Volume of Thrombocytes, MPV: Mean Platelet Volume, PDWc: Platelet Distribution Width. 
Citation: Angulo A, Sebastián I, Martínez FJ, Torregrosa R, Martín-Martínez JM, et al. (2016) Comparative Effectiveness of Cyanoacrylate Bioadhesives and Monofilament Suture in Wound Healing: A Histopathological and Physicochemical Study in New Zealand White Rabbit. J Cytol Histol 7: 395. doi:10.4172/2157-7099.1000395

Page 6 of 8
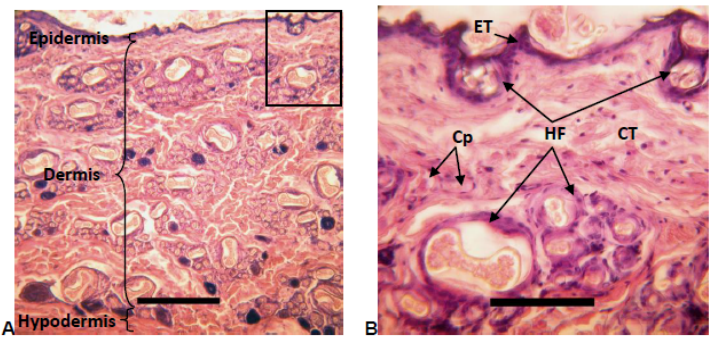

Figure 6: A) Normal skin rabbit stained with Hematoxylin-eosin. Slice is perpendicular to the skin surface (on top). Scale bar: $300 \mu \mathrm{m}$. B) Magnification of the square area in A. Scale bar: $100 \mu \mathrm{m}$. Epidermis: Epithelium tissue (ET) of cells stained in purple (hematoxylin). Hair follicles (HF) are on surface. Dermis: Loose connective tissue (CT) with isolated fibroblast nuclei in purple, collagen fibres and elastic fibres cut in rose in different spatial directions and ground substance in white between abundant hair follicles (HF: white spaces with several pink eosin hairs surrounded by purple epithelium) and some capillaries (Cp). No evidence of inflammatory reaction (abundant very purple leukocytes) neither fibrosis (dense connective tissue with a predominance of very pink collagen fibres). Hypodermis: Connective tissue under the dermis.
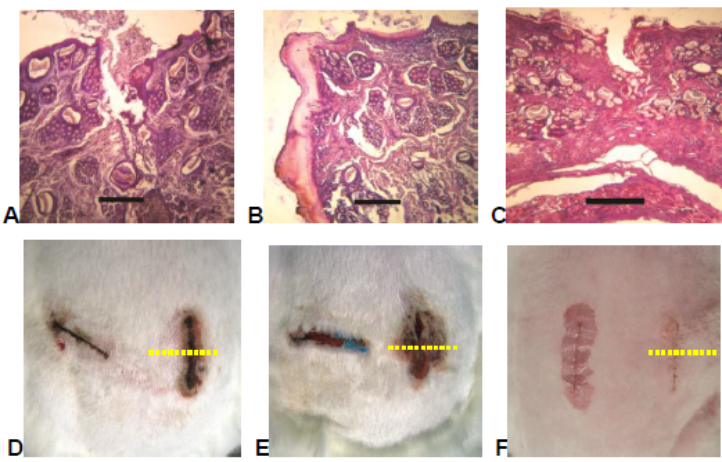

Figure 7: Histopathological and clinical appearance of wounds closed with $E C N$ $(A, D), B C N(B, E)$ and $\mathrm{OCN}(C, F)$ adhesives after 3 days. Right side of rabbit is on the right of pictures $(D, E, F)$. Yellow dotted lines: cross sections of wounds corresponding to slices with skin surface on the top. Scale bar: $300 \mu \mathrm{m}$. The application of the ECN and OCN produced wound edges lightly separated on the surface but joined at the bottom (Degree 3 in Table 1) (A and $\mathbf{C}$ pictures). In B picture one edge of open wound with remains of adhesive is shown (Degree 1 in Table 1)
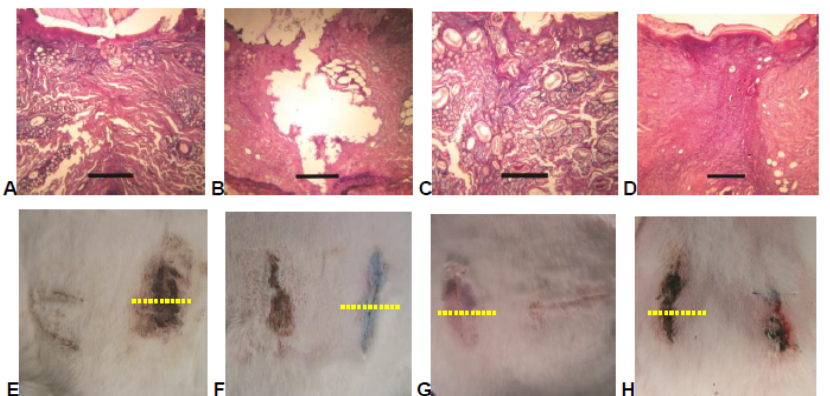

Figure 8: Histopathological and clinical appearance of wounds closed with $\operatorname{ECN}(A, E), B C N(B, F)$ and $\operatorname{OCN}(C, G)$ adhesives and suture $(D, H)$ after 7 days. Right side of rabbit is on the right $(E, F, G, H)$. Yellow dotted lines: cross sections of wounds corresponding to slices with skin surface on the top. Scale bar: $300 \mu \mathrm{m}$. Pictures A, C and D show that the use of ECN or OCN adhesive renders the wound closed and the skin tissue shows almost normal structure (degree 5 in Table 1) as compared to the use of suture (Degree 4 in Table 1). When $\mathrm{BCN}$ adhesive is used (B picture), the wound edges are totally separated (Degree 2 in Table 1).
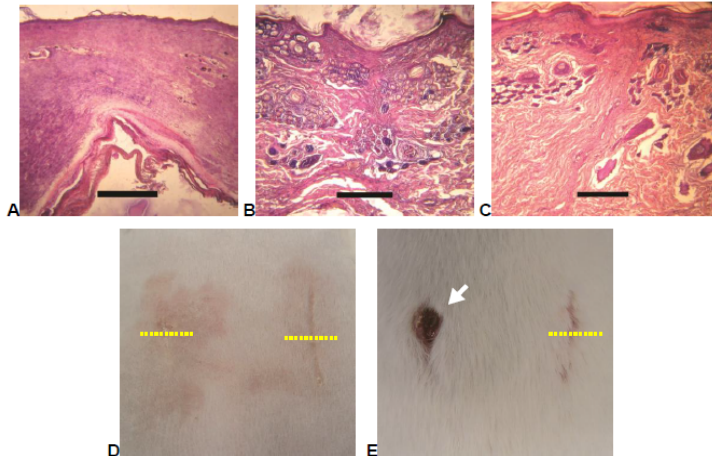

Figure 9: Histopathological and clinical appearance of wounds closed with BCN (A,D-left), OCN (B,D-right) and adhesives and suture (C,E) after 14 days. Right side of rabbit is on the right $(D, E)$. Yellow dotted lines: cross sections of wounds corresponding to slices with skin surface on the top. Arrow: open wound. Scale bar: $300 \mu \mathrm{m}$. In B picture the skin shows almost normal structure with very little evidence of fibrosis (Degree 6 in Table 1) as compared with A (Degree 4 in Table 1) and $\mathbf{C}$ (Degree 5 in Table 1) pictures.

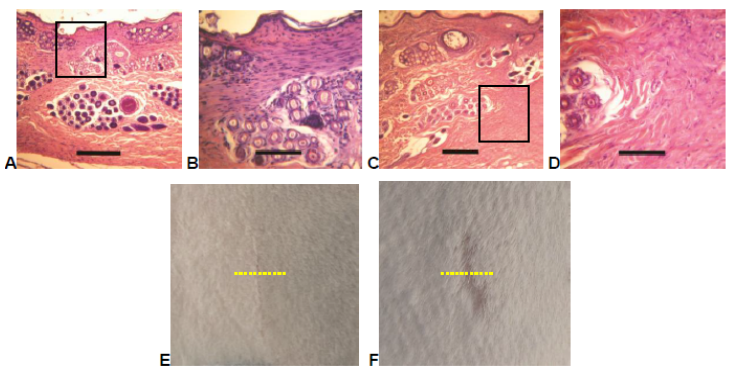

Figure 10: Histopathological and clinical appearance of wounds closed with $\operatorname{ECN}(A, B, E)$ adhesive and suture $(C, D, F)$ after 28 days. Right side of rabbit is on the right $(E, F)$. Yellow dotted lines: cross sections of wounds corresponding to slices with skin surface on the top. Scale bar: $300 \mu \mathrm{m}(\mathbf{A}, \mathbf{C}), 100 \mu \mathrm{m}$ (B,D magnification of square areas). $\mathrm{A}$ and $\mathrm{C}$ pictures

The incisions made in the surgical procedure were healed with conventional suture and by using the three cyanoacrylate adhesives of different alkyl chain length. The general appearance and clinical course of all animals after surgery was good, with no apparent disease register data. Biochemical and haematological values were within the normal range for rabbits [18,21-23], which suggests good biocompatibility of the adhesives. Histological features of the tissues of the layers of healthy normal skin rabbit are given in Figure 6.

At the end of the surgical procedure when suture or adhesives were used, most of the incisions in the rabbit skin were closed in full by primary closure [24]. The normal skin appearance, as showed in Figure 6 , was recovered when ECN (Figures $7 \mathrm{~A}, 7 \mathrm{D}, 8 \mathrm{~A}$ and $8 \mathrm{E}$ ) or OCN (Figures 8C, 8G, 9B and 9D-right) adhesives were used. However, using the evaluation criteria described in Table 1 , the CT and HF were not well identified in wound closed with BCN (Figures 9A and 9D-left) and suture (Figures $8 \mathrm{D}, 8 \mathrm{H}, 9 \mathrm{C}, 9 \mathrm{E}, 10 \mathrm{C}, 10 \mathrm{D}$ and $10 \mathrm{~F}$ ). The results were worse when the rabbit removed itself off the dressing and gnawing the stitches from the incision (Figures $1 \mathrm{D}$ and $9 \mathrm{E}$ ) or the adhesive was very aggressive by reacting with the tissue (Figures $7 \mathrm{~B}, 7 \mathrm{E}, 8 \mathrm{~B}$ and $8 \mathrm{~F}$ ).

An excess of bioadhesive quantity or a deficient confronting edges of the wound caused delay in closure (Table 1 and Figures 7A, $7 \mathrm{~B}, 7 \mathrm{D}, 7 \mathrm{E}, 8 \mathrm{C}$ and $8 \mathrm{G}$ ). In the most of those cases, a secondary closure [24] of the wound were produced until healing develops a granulation tissue (with several inflammatory reaction degrees and varied 
Citation: Angulo A, Sebastián I, Martínez FJ, Torregrosa R, Martín-Martínez JM, et al. (2016) Comparative Effectiveness of Cyanoacrylate Bioadhesives and Monofilament Suture in Wound Healing: A Histopathological and Physicochemical Study in New Zealand White Rabbit. J Cytol Histol 7: 395. doi:10.4172/2157-7099.1000395

Page 7 of 8

preservation of dermis and epidermis structures) from deep to surface of skin injured (Table 1). The inflammatory reaction, the absence of HF and disorganization of collagen fibres of the dermis was higher in the sutured junctions than in the cuts closed with cyanoacrylate adhesives (Figures 8D, 9C and 10D) show that the skin have recovered an almost normal aspect, but fibrosis is more evident in the wound closed with suture (Degree 5 in Table 1) than with bioadhesive (Degree 6 in Table 1).

Considering the evolution with time of the wound after surgery, in general, the performance obtained by using bioadhesives is better than by using suture. After only 3 days, ECN and $\mathrm{OCN}$ adhesives are rare efficient in spite of the most superficial layer is separated (Figure 7). Until 7 days the suture is absolutely inefficient for closing the wound (Figure 8). After 14 and 28 days, the use of both suture and adhesives for closing the wounds are very similar, but the skin tissues are better recovered when the adhesives are used (Figures 9 and 10).

Compared to conventional monofilament suture, the three cyanoacrylate adhesives (ECN, BCN, OCN) show some advantages in handling time, haemostasis achieved immediately upon application, excellent confronting edges and no incisions plaque retention. No significant differences were found between the binding efficiency comparing longitudinal and transverse incisions using whatever combination of suture and cyanoacrylate adhesives on the same or different animals (Figures 7-10). Furthermore, the inflammatory reaction and disorganization of collagen fibres of the dermis was higher in the wound sutured with respect to those closed with adhesive $[11,19]$.

The structure and immediate adhesion of the cyanoacrylate adhesives with different alkyl hydrocarbon chain length can be related to their performance in wound healing of rabbit skin. The ethyl cyanoacrylate is mainly composed of monomers and it shows high adhesive strength causing an effective closure of the incisions on rabbit skin. Because of its quick polymerization, there is not the chance of having remaining unreacted monomers on the wound surface leading to a fast healing and effective tissue regeneration. On the other hand, the existence of dimers in n-butyl cyanoacrylate does not favour quick healing and they can remain on the wound surface delaying the healing and causing reactions with the neighbouring tissues. Finally, the wounds closed with n-octyl cyanoacrylate show slower tissue regeneration because the important existence of oligomers of different length which will retard the healing. As a consequence, the structure of the cyanoacrylate monomer can be related to its performance as adhesive in wound healing of rabbit skin, the optimal performance was obtained by using the ethyl cyanoacrylate adhesive.

\section{Conclusions}

The use of cyanoacrylate adhesive was as favourable as surgical suture on rabbit skin being faster, easy to handle and apply, painless, having less risk of infection, excellent aesthetic results, and significant cost savings before and after surgery to reduce the need for anaesthesia and postoperative cures.

The structure of the cyanoacrylate monomer can be related to its performance as adhesive in wound healing of rabbit skin, the optimal performance was obtained by using the ethyl cyanoacrylate adhesive. Whereas the ethyl cyanoacrylate was mainly composed of monomer, the n-butyl cyanoacrylate contained monomer and some dimmers, and the n-octyl cyanoacrylate had only a minor content of monomer.

The immediate adhesion of the cyanoacrylate adhesives decreases by increasing the length of the alkyl hydrocarbon chain. The adhesive strength of the joints produced with cyanoacrylates were high and sufficient to maintain the tissues jointed during wound closure and the cyanoacrylate adhesives with lower alkyl hydrocarbon chain length had greater efficiency in tissue repair.

Finally, the cyanoacrylate adhesives have a biological tolerance similar to the surgical monofilament suture, so they are an alternative to conventional suture in animal surgery.

\section{Acknowledgements}

Financial support of the Spanish Research Funding Agency (MICYNN) PET2008-0264 and MAT2009-10234 projects - is acknowledged. Authors thank Mr. Juan Carlos Lillo-Garrigós for pig skin supply.

\section{References}

1. Harcourt-Brown F (2002) Textbook of rabbit medicine. UK: ButterworthHeinemann $p p: 410$

2. Russell WMS, Burch RL (1959) The Principles of Humane Experimental Technique. Methuen, London.

3. Boothe HW (1993) Suture Materials, Tissue Adhesives, Staples and Ligation Clips. En Slatter D Textbook of Small Animal Surgery, WB Saunders, Philadelphia, USA.

4. Coover HW, Joyner FB, Sheare TH, Wicker TH (1959) Chemistry and performance of cyanoacrylate adhesives. Soc Plast Eng J 15: 413-417.

5. Vinuela FV, Debrun GM, Fox AJ, Girvin JP, Peerless SJ (1983) Dominanthemisphere arteriovenous malformations. AJNR Am J Neuroradiol 4: 959-966.

6. Singer AJ, Thode HC (2004) A review of the literature on octylcyanoacrylate tissue adhesive. Am J Surg 187: 238-248.

7. Forssell H, Aro H, Aho AJ (1984) Experimental osteosynthesis with liquid ethy cyanocrylate polymerized with ultrasound. Arch Orthop Trauma Surg 103: 278-283.

8. Bozkurt MK, Saydam L (2008) The use of cyanoacrylates for wound closure in head and neck surgery. Eur Arch Oto-Rhino-L 265: 331-335.

9. Vote BJT, Elder MJ (2000) Cyanoacrylate glue for corneal perforations: a description of a surgical technique and a review of the literature. Clin Exp Ophthalmol 28: 437-442.

10. Pascual-Sánchez V, Mahıques-Bujanda MM, Martín-Martínez JM, Alió-Sanz $\mathrm{JL}$, Mulet-Homs E (2003) Synthesis and characterization of a new acrylic adhesive mixture for use in ocular strabismus surgery. The Journal of Adhesion 79: 1067-1089.

11. Ahn HB, Shin DM, Roh MS, Jeung WJ, Park WC (2011) A comparison of 2-octyl cyanoacrylate adhesives versus conventional suture materials for eyelid wound closure in rabbits. Korean J Ophthalmol 25: 121-127.

12. FY (2004) ODE Annual Report-Part 2-Industry Information Original PMA/HDE Approvals for Fiscal Year 2004 Significant Medical Device Approvals.

13. (2007) Decree of Council on the protection of animals used for experimental and other scientific purposes in Valencia.

14. (2005) Royal Decree on the protection of animals used for experimental and other scientific purposes.

15. (2007) Law for the care of the animals on his farm, transport, experimentation and sacrifice.

16. Directives (2010) Directive 2010/63/EU of the European Parliament and of the Council of 22 September 2010 on the protection of animals used for scientific purposes.

17. UNE-EN ISO 10993-1 (2004) Use of International Standard ISO-10993 Biological Evaluation of Medical Devices Part 1: Evaluation and Testing. Draft Guidance for Industry and Food and Drug Administration Staff.

18. Madariaga A, Sebastián I, Martínez F, Angulo A, Torregrosa R, et al. (2011) Reference values of biochemical and hematological parameters in New Zealand Rabbit. SECAL Congress XI. Valencia.

19. Madariaga A, Sebastían I, Martínez F, Torregrosa R, Martín JM (2013) Comparative study of wound healing in New Zealand rabbit using adhesive and suture. 12th FELASA SECAL Congress, Barcelona.

20. Dossi M, Storti G, Moscatelli D (2010) Synthesis of poly (alky cyanoacrylates) as biodegradable polymers for drug delivery applications. Macromol Symp 289: 124-128. 
Citation: Angulo A, Sebastián I, Martínez FJ, Torregrosa R, Martín-Martínez JM, et al. (2016) Comparative Effectiveness of Cyanoacrylate Bioadhesives and Monofilament Suture in Wound Healing: A Histopathological and Physicochemical Study in New Zealand White Rabbit. J Cytol Histol 7: 395. doi:10.4172/2157-7099.1000395

Page 8 of 8

21. Hinton M, Jones, DRE, Festing MFW (1982) Haematological findings in healthy and diseased rabbits, a multivariate analysis. Lab Anim 16: 123-129.

22. Alemán CL, Noa M, Más R, Rodeiro I, Mesa R, et al. (2000) Reference data for the principal physiological indicators in three species of laboratory animals. Lab Anim 34: 379-385.
23. Mizoguchi Y, Matsuoka T, Mizuguchi H, Endoh T, Kamata R, e t a I . (2010) Changes in blood parameters in New Zealand White rabbits during pregnancy. Lab Anim 44: 33-39.

24. Toon CD, Ramamoorthy R, Davidson BR, Gurusamy KS (2013) Early versus delayed dressing removal after primary closure of clean and clean-contaminated surgical wounds. Cochrane Database of Systematic Reviews 9: CD010259. 